\section{Experiences of Student Affairs Professionals in Facilitating Co-Curricular Leadership Development Programmes in South African Universities}

\author{
Gugulethu Xaba
}

\begin{abstract}
Despite the important role that student affairs practitioners play in supporting universities to produce well-rounded graduates, few studies have been conducted on their lived experiences. This article examines the challenges confronted by these professionals in interacting with student leaders and facilitating leadership programmes in South African universities. A qualitative methodology was adopted and semi-structured interviews were conducted with 20 student affairs practitioners responsible for facilitating student leadership development programmes. A focus group discussion was also held with six student affairs experts. The findings point to a lack of seamlessness in the structure, staffing, and operation of these programmes, as well as a lack of university support to professionalise student affairs. Furthermore, student leadership development programmes were found to lack proper theoretical grounding.
\end{abstract}

Key words: Student leadership development programmes, students, student affairs professionals

Malgré le rôle important que jouent les praticiens des affaires étudiantes pour aider les universités à produire des diplômés bien équilibrés, peu nombreuses sont les études qui ont été menées sur leurs expériences vécues. Cet article examine les défis auxquels sont confrontés ces professionnels dans l'interaction avec les leaders étudiants et la facilitation

ABOUt THE AUthoR: GUgUlethu Xaba, Tshwane University of Technology, South Africa. Email: guguxaba@yahoo.com des programmes de leadership dans les universités sud-africaines. Une méthodologie qualitative a été adoptée et des entretiens semi-structurés ont été menés avec 20 praticiens des affaires étudiantes chargés de faciliter les programmes de développement du leadership étudiant. Une discussion en groupe a également eu lieu avec six experts en affaires étudiantes. Les résultats soulignent un manque de transparence dans la structure, dans la dotation en personnel et dans le fonctionnement de ces programmes, ainsi qu'un manque de soutien universitaire pour professionnaliser les affaires étudiantes. En outre, les programmes de développement du leadership des étudiants n'ont pas une base théorique adéquate.

Mots clés: programmes de développement du leadership étudiant, étudiants, professionnels des affaires étudiantes

\section{Introduction and background}

Student affairs practitioners enjoy flexibility in providing leadership education because they do not face the limitations of classroom availability, course enrolment management, or faculty teaching rotations that confront curricular leadership programmes (Dunn et al., 2019, p. 94). Currently, more students receive leadership education from student affairs offerings than academic leadership courses, yet little is known about the leadership educators who work in the more than 2 ooo leadership programmes worldwide (Jenkins, 20I9, p. I4I; Dunn et al, 20I9, p. 94). Student affairs professionals can play a vital role in the daily lives of students and institutions since they interact with students throughout their studies rather than being limited to a single year or semester of course instruction as is the case with many faculty-to-student interactions (Martin, Smith, Takewell and Miller, 2020, p. I49; Selznick, 2013, p. I2). The study on which this article is based sought to understand the challenges experienced by student affairs professionals in delivering these programmes. Its findings will be useful in planning and reviewing the programmes offered.

Student affairs plays a critical role in the student experience and the professional knowledge, skills, attitudes, and commitments that define the profession are expected of professionals across all areas of specialisation (ACPA and NASPA, 20I5). The following research question guided the study:

What are the challenges and experiences of leadership educators as they execute their responsibilities of facilitating co-curricular leadership development programmes at various South African universities

Literature review

Leadership as a discipline, leadership education as a field, and the leadership 
educator as a profession are still in their infancy, but are rapidly evolving (Guthrie and Jenkins, 20I8, p. xxvi). Hence, there is a paucity of research on the experiences of student affairs professionals that facilitate student leadership development programmes (SLDPs) in universities, particularly in the South African context. Indeed, Speckman and Mandew (20I4, p. I) note that there is a lacuna in home-grown student affairs research in South Africa and that there is little that is original about the practice and philosophy of most professionals in this field. Wilson (2013, p. 49) asserts that the increasingly dynamic nature of the student population calls for dynamic student affairs professionals who are capable of understanding, interacting, and working with diverse students.

Guthrie and Jenkins (2018, p. 3) define leadership education as the pedagogical practice of facilitating leadership learning with the goal of building human capacity. It is informed by leadership theory and research, which takes place in both curricular and co-curricular educational contexts. Leadership educators are responsible for presentation of curricular and co-curricular leadership programmes to students. This study focused on leadership educators who are student affairs professionals that are responsible for SLDPs offered outside the classroom environment. According to Dunn et al. (20I9, p. I07), student affairs leadership educators have a responsibility to develop leadership competencies in others. However, such development begins with self; once they have demonstrated competence, they work with emerging student affairs professionals, and expand their efforts to other members of the campus community.

Wilson (2013) explored the multicultural competence of student affairs professionals responsible for leadership education. The sample included full-time student affairs professionals with at least a bachelor's degree, and self-identified faculty in higher education. The study found that student affairs professionals responsible for leadership education are in a unique position to facilitate and foster a campus environment that is inclusive and affirming. Therefore, multicultural competence is an essential competency that they should seek to enhance and infuse in their daily practice.

Dunn et al. (20I9) investigated the characteristics of a collegiate student affairs leadership educator. As this study was part of a larger study to elicit and refine group opinions or judgements, a classic Delphi approach was used to purposively select participants based on their substantial experience or expertise in the subject matter. The participants included student affairs practitioners responsible for hiring and training, and student affairs preparatory programme coordinators responsible for curriculum design and instruction. The study found that student affairs practitioners are leadership educators who are familiar with and practice leadership theories, teach academic credit-bearing leadership courses, and/or conduct leader- ship research; none of which are typical job responsibilities of entry-level student affairs practitioners.

Jenkins' (20I9) phenomenological study explored the lived experiences of becoming and being a leadership educator in higher education. A snowball sample of I3 leadership educators from four states and II universities participated in the study. They described how their interest in a development focused field often serendipitously led them to leadership education and described their work as rewarding and as enabling them to exercise creative authority.

Nkonoane (20I5) sought to identify desirable competencies of student affairs professionals in South African higher education institutions, while Harding and Matkin's (20I2) phenomenological inquiry focused on educators' experiences of teaching leadership and Seemiller and Priest (20I7) explored leadership educators' professional identities. However, there is a lack of research on the student affairs professionals responsible for the delivery of SLDPs in the South African context. This study aimed to fill this gap by focusing on the lived experiences of student affairs professionals from six of the country's universities.

\section{Research methodology}

The purpose of the study was to explore the lived experiences of student affairs professionals who deliver SLDPs at various South African universities and to solicit their views with respect to the design, presentation, evaluation and reporting mechanisms in relation to such programmes. A qualitative research design was appropriate as it enables the researcher to understand participants in terms of their own description of the world (Mouton, 200I, p. I94).

Data was collected by means of face-to-face and telephonic interviews with 20 student affairs professionals in six South African universities, with each interview lasting between 30 and 45 minutes. Table I below lists the number of participants per university.

Table 1: Number of participants per university

\begin{tabular}{|l|l|}
\hline University one & 4 participants \\
\hline University two & 2 participants \\
\hline University three & 3 participants \\
\hline University four & 3 participants \\
\hline University five & 5 participants \\
\hline University six & 3 participants \\
\hline
\end{tabular}


The student affairs professionals were purposively selected as they play a major role in designing, presenting, evaluating and communicating the various SLDPs offered in the universities and thus have in-depth knowledge of such programmes. Given that the data was collected by means of semi-structured interviews, data collection was guided by saturation point. The point of saturation was reached when the twentieth participant was interviewed. Cluster sampling was employed to select the universities. The researcher divided the universities into groups or clusters, identified convenient, naturally occurring groups rather than individual subjects, and randomly selected some of these units (McMillan and Schumacher, 20I0, p. 134). Three clusters were formed based on the different categories of universities in South Africa, namely, traditional universities, universities of technology and comprehensive universities.

A focus group was conducted to obtain a detailed understanding of the issues (Nyumba et al., 20I7, p. 20) and to test the completeness, suitability and plausibility of the framework for evaluating SLDPs informed by the research process. It comprised of experts who were purposely selected for their knowledge and experience. They included:

- A director of student affairs and curriculum design specialist at a research university;

- A senior academic and student leadership development specialist and a counselling psychologist at a research university;

- A senior student affairs researcher and quality development specialist at a university of technology;

- A leadership development specialist and experienced senior student affairs officer, and professional speaker employed as the executive director of a training organisation; and

- A director of development grants and higher education policy consultant and quality assessment specialist at a health sciences university.

As suggested by Wibeck et al. (2007, p. 266), the focus group discussion was facilitated by an interview guide and was held by video using the Webex (Cisco) online platform. The meeting was recorded and the researcher took notes which were used in data analysis.

Data from the interviews and the focus group discussion were analysed using Tesch's method of qualitative analysis as described in Creswell (2009). The recorded information was transcribed verbatim and content analysis was employed to identify themes and categories, followed by coding. Tesch (I992, pp. I42-I45) provides detailed guidelines to develop a system for unstructured qualitative data following eight steps, namely, reading the entire transcript carefully to obtain a sense of the whole and to jot down ideas; selecting one case and understanding what it is about and then recoding thoughts in the margin; making a list of all the themes and clustering similar ones; applying the themes to the data, abbreviating them as codes, and writing them in appropriate segments of the transcripts to determine whether new categories and codes emerge; finding the most descriptive wording for the themes and categorising them to show the relationships; making a final decision on the abbreviation for each category and alphabetising the codes; assembling the data belonging to each category before preliminary analysis is performed; and recoding material if necessary.

\section{Findings}

This section presents the study's findings under II themes, each with subthemes. The themes were developed on the basis of the questions posed to the student affairs professionals on their challenges and experiences as they facilitate co-curricular leadership development programmes at South African universities.

Perceptions of the ideal SLDP educator

The participants were asked to share their opinions on what they considered to be an ideal SLDP educator. Three themes emerged from their responses, namely, qualifications, characteristics and adaptability to change.

\section{Qualifications}

The participants suggested that an ideal leadership educator should have a degree in Education or Student Affairs Studies. Alternatively, those who have qualifications in other fields should register for a postgraduate degree in Student Affairs to gain knowledge on the student development theories and techniques. This view is supported by Nkonoane (2015, p. 89) who highlighted the importance of a formal preparation programme for student affairs practitioners. The participants also stated that a leadership educator should have sound research acumen, and writing and presentation skills. Furthermore, he/she should be able to conduct training needs analysis, and have the ability to design and develop learning materials. Furthermore, they should be familiar with a variety of methodologies (workshops, tours, seminars, adventure-based learning, technology, etc.). The educator should be able to evaluate programmes and assess students' levels of development on an on-going basis. The participants added that a leadership educator should demonstrate competence in managing projects and be able to communicate with students when they plan and organise activities and events. Finally, they stated that a leadership educator should be well acquainted with student leadership development and coaching theories.

The qualifications and competencies highlighted above closely resemble the ten professional competency areas that the American College Personnel 
Association (ACPA) and National Association of Student Personnel Administrators (NASPA) consider as essential knowledge, skills, and dispositions for student affairs educators, regardless of their functional area or specialisation. These are (I) Personal and ethical foundations (PPF); (2) Values, philosophy, and history (VPH); (3) Assessment, evaluation, and research (AER); (4) Law, policy, and governance (LPG); (5) Organisational and human resources (OHR); (6) Leadership (LEAD); (7) Social justice and inclusion (SJI); (8) Student learning and development (SLD); (9) Technology (TECH); and (IO) Advising and supporting (A/S) (ACPA and NASPA, 20I5).

\section{Characteristics}

Most $(\mathrm{n}=\mathrm{I5})$ of the participants believed that a leadership educator should enjoy working with students. He/she should understand students' basic needs, contemporary views and sentiments and be able to accommodate those that might not be easy to work with. Some added that he/she should have been actively involved in youth and student development programmes in their student days. Leadership educators should be activists in their own right, with a natural inclination for student development work and the ability to engage with topical issues affecting young people. They should be passionate about student development and self-development. The participants also proposed that a leadership educator needs to have certain personality traits such as being easily approachable and making students feel at ease and comfortable. They suggested that he/she needs to be a peacemaker and a neutral person who is able to address conflict between students. The leadership educator was described as a life coach and a mentor. These descriptions are in line with the desired professional behaviours identified by Jenkins and Owen (2016) for those who direct or coordinate co-curricular leadership programmes. Figure I below sets out these behaviours.
Figure 1: Suggested competencies for leadership educators

Knowledge of the history and current trends in leadership theories, models, and philosophies;

- An understanding of the contextual nature of leadership;

- Knowledge of organisational development group dynamics, strategy for change, and principles of community;

- Knowledge of how social identities and dimensions of diversity influence leadership;

- The ability to work with a diverse range of students;

- The ability to create, implement and evaluate student learning as a result of leadership programmes;

- The ability to effectively organise learning opportunities that are consistent with students' stages of development;

- The ability to use reflection in helping students understand leadership contexts;

The ability to develop and assess student learning outcomes.

\section{Source: Jenkins and Owen, 2016}

Adaptability to change

All the participants stated that it is crucial for a student affairs professional to be flexible and be able to adjust to change. They noted that the higher education environment is prone to change due to the fact that members of Executive Management are appointed on five-year contracts. Each new management team introduces new ways of doing things. This requires student affairs professionals to be adaptable to change and to anticipate such changes. The participants added that the profiles of university students are also changing. Universities South Africa (20I8, p. 4) notes that student populations are becoming more diverse, representing vastly different backgrounds; many students are poor; are first-generation students and are older. The large majority are also tech-savvy, calling for different approaches, modes of communication and forms of engagement. While diversity brings new challenges to higher education institutions, it also creates opportunities. The participants indicated that it is important for student affairs professionals to remain up-to-date by reading the professional literature, building their skills, attending conferences, enhancing their technological literacy, and engaging in other professional development activities. All the participants agreed that adaptability should include understanding diverse international dynamics, different cultures, various global environments and how different people across the world view things. This finding concurs with Major and Mangope's (2014, p. 24) study that concluded that student affairs professionals are decision-makers who play a vital role in addressing multicultural issues on campuses; their unique positions call for the integration of multicultural awareness, knowledge and skills in practice. 
Theoretical models for grounding SLDPs

The participants were asked to indicate what theoretical model they used to ground the programmes that they present to students. The theme that emerged from this section is lack of proper theoretical grounding. Most $(n=I 6)$ of the participants indicated that their universities had not adopted any specific theory for the grounding of their SLDPs. All of them indicated that they primarily base their philosophical orientation on their strategic overview and the adopted graduate attributes. Only two participants stated that they were using some theory and models to ground their programmes. It is clear from the interviews that some participants were not familiar with the various student development theories although they had worked in student affairs for a number of years. The participants' experience ranged from three to 23 years in this field. This does not fit well with Long's (2012, p. 42) assertion that student affairs exists as a profession to support student learning and success; thus student development theories, which describe how students grow and change throughout their college experience, are the cornerstone for the theoretical framework of student affairs.

The elements of ideal SLDPs

The participants were asked to share their thoughts on what they considered to be the elements of an ideal SLDP. Three sub-themes emerged, namely, adequate resources; balanced content and meeting students' needs and aspirations.

\section{Adequate resources}

All the participants pointed to the need for additional funding that would enable them to enrol more students in SLDPs and improve their delivery using multiple methods. They noted that most of their units are underfunded and understaffed and rely on inexperienced volunteers, which compromises the quality of their output. UNESCO (2009) states that the main challenges confronting student services are internationalisation of higher education, a lack of network resource professionals, and funding; and students' diverse and growing needs due to massification of higher education. The participants highlighted to need for additional staff as well as skilled development facilitators to design, present and evaluate SLDPs. They also pointed to the need to link with researchers in order to enrich their programmes. These findings are in line with those of Pansiri and Sinkamba (20I7, p. 56) who observe that universities' budget priorities and decisions are skewed towards academic departments. Nkonoane (2015, p. II4) maintains that, while it is generally accepted that universities' core business is the "academic project", student affairs practice plays an equally significant role in ensuring that students achieve their academic goals. There is thus a need to adopt a Resource Allocation Model (RAM) to ensure that student affairs divisions are adequately equipped to develop and sustain development programmes.

\section{Balanced content}

The participants also raised the need for balanced content in well-structured SLDPs that offer both contact and virtual sessions. Furthermore, students should be provided with opportunities to practice what they learn by engaging in community service. Lin and Shek (2019, p. II59) argue that class contact learning is more effective than leadership programmes that involve outside activities because it can reach more students and is less costly. They therefore state the need for balance between content presented through contact sessions and that presented virtually. Contact sessions help to develop rapport between the facilitators and students, while online provision develops independence among student participants. Some of the participants suggested that some of the content should be offered online in order to address timetable challenges and take advantage of the fourth industrial revolution. They agreed with Universities South Africa's (20I8) observation that today's students are tech-savvy, but noted that only a few universities utilise online platforms and blackboards for SLDPs. Furthermore, providing content online would enable students to participate in the programme in their own time at their own pace. However, Ahlquist (20I5, p. 83) cautions that, students may have grown up in the presence of technologies and digital advances, but this does not necessarily mean that they are literate or competent in using them. The participants proposed that universities should offer digital training to student affairs professionals and ensure that the university digital infrastructure has the capacity to include SLDP offerings.

Meeting students' needs and aspirations

The participants stated that students' needs and aspirations are a key element that guides the design of SLDPs. All of them indicated that it is important for the facilitator to ascertain students' expectations and their reasons for enrolling in the programme before designing and presenting it. When expectations are met, participation improves. This is in line with Robinson and Glanzer (2016, p. Io) who note the need to understand students' expectations. The participants also agreed that the programme design should be student-centred from the beginning to the end. In the beginning, a needs analysis should be conducted, while at the end, feedback should be obtained from the participants as part of the evaluation of the programme. Continuous assessment should occur throughout the programme to determine if the desired learning is taking place. 
The study found that only two of the six institutions involved students and other stakeholders in their planning process. Larson and Eccles $(2005$, p. I63) highlight the need for programme participants to be involved in the planning. Morgan and Orphan (20I6) propose that campus stakeholders need to dedicate more time and attention to intentionally crafting programmes and practices that leverage democratic student engagement. Johnson (2019, p. 608) argues that student affairs professionals should meaningfully involve students in resolving the problems that they face, such as creating inclusive environments on campus.

\section{The ideal content for SLDPs}

The participants were asked to share their ideas on what they considered to be the ideal content of SLDPs. Four sub-themes emerged, namely, Personal Development, Communication Skills, Leadership Development and General Organisational Skills.

\section{Personal development}

The participants agree that students should be introduced to personal development by focusing on Ubuntu, personal mastery, and advancing university graduate attributes, with some of the view that Ubuntu should be a compulsory module. According to Msila (2015, p. I), Ubuntu is an old African concept, a way of life that can be useful to teach leadership and management skills. It involves sacrificing for others, and caring and protecting fellow human beings. Ubuntu is based on the premise that everything in one's environment is crucial for one's existence as well as that of one's fellow human beings. The participants indicated that it is a uniquely South African concept that is relevant to inculcate respect for oneself and others in student leaders.

Other participants noted the need to introduce student leaders to the principles of personal mastery which, amongst others, addresses personality traits, a personal strategic plan and living a balanced life. Bui, Ituma and Antonacopoulou (2013, p. I69) note that personal mastery has attracted growing interest in recent years due to its association with learning capability; hence, it is hypothesised by a set of antecedents such as competence, personal values, personal vision, motivation, individual learning, training and development, and organisational culture. Finally, some of the participants argued for the use of their university's graduate attributes as a key subject to set a benchmark for personal development. Osmani, Weerakkody and Hindi (20I7, p. 55) argue that the first step in getting graduates to think about what they can offer to the world and potential employers is that they recognise the importance of soft skills.

The participants also maintained that it is important to address areas that the university has identified as requiring attention to either address emerging risks amongst young people or national or even international issues. During the Fees Must Fall (\#FMF) movement, student leadership programmes incorporated issues of social justice and in recent times, the topics of toxic masculinity and sexual orientation have become critical. Finally, there was overwhelming agreement among the participants that promoting academic success should be central in all programmes since the students are first and foremost at university to obtain training and an academic qualification.

\section{Communication skills}

The participants highlighted that there should be a compulsory module on communication in all SLDPs. They noted that leadership depends on the leader's ability to communicate a message and vision. Students also need to learn how to engage respectfully with others and handle disagreements in a civil manner. They thus need to master the skill of reasoning. The aspects of communication listed by the participants included being street smart, understanding different cultures and people, learning the importance of verbal and nonverbal communication and the value of listening to others. Osmani, Weerakkody and Hindi (20I7, p. 56) list communication as the number one graduate attribute valued by potential employers, while Seemiller (20I4, p. 87) includes it among the six student leadership competencies that are necessary in the 2Ist century. The latter notes that being able to communicate enables leaders to fully express their intended meaning, show that they care and that they are listening and to inform, inspire, influence and negotiate in a non-written format.

\section{Leadership development}

The participants agreed that a variety of methods can be used in SLDPs. According to the Council for the Advancement of Standards in Higher Education (CAS) (2006), institutions should design a range of student leadership-related activities. The participants proposed that the leadership module should be grounded in well-researched student development philosophies, theories and standards. It should aim to develop ethical leadership, respect, team building and humility and should include activities to demonstrate what students have learned, such as community development initiatives and projects. Rosch, Spencer, and Hoag (20I7, p. I32) propose that a comprehensive model for leadership education in a university context should include: (I) a philosophy of leadership, (2) an explicit set of competencies, (3) a list of spaces for learning and practicing leadership behaviours, and (4) a plan for assessment and evaluation of developmental efforts at the student and campus unit level. 


\section{General organisational skills}

The participants felt that it is important to include general organisational skills as a basic module in all programmes. Students should be taught how to run successful organisations and they thus need to learn how to plan, organise and manage projects. All participants also indicated that student leaders need to acquire administrative skills like report writing, presentation, time management, management of meetings and management of organisational finances. Weiss (20I9, p. 4I) lists soft skills such as operational thinking and decision making among the top ten skills that facilitate students' career success. Lebrón et al. (20I7, p. 85) argue that students can gain such organisational and operational skills by participating in universities' Professional Based Organisations (PBOs), since their unique context offers an on-campus space to learn the leadership skills required for a particular profession.

Student affairs professionals' perceptions on the impact of SLDPs

The participants were requested to share their perceptions on the impact of the SLDPs they presented. The theme that emerged was reliance on circumstantial evidence to assess impact. While they all described their unit's programmes as having an impact, they relied on circumstantial evidence to reach this conclusion. This includes feedback from previous participants and staff members from departments that refer students to the programmes. The participants indicated that students who completed the SLDP became more active on campus and took up leadership positions in student societies, clubs and governance structures. Some participants based their assumptions on feedback from evaluation forms and portfolios of evidence compiled by students. However, there was no evidence that these tools provide relevant data, use multiple data-gathering techniques and disaggregate the data as suggested by Oburn (2005, p. I9). Most of the respondents indicated that they did not have a proper system to evaluate the impact of their programmes.

\section{Students' preferred learning environment}

The participants were requested to share their opinions on what they considered to be students' preferred learning environment. Three themes emerged: Experiential and involved learning environment; safe spaces to freely engage and express themselves and an off-campus outdoor learning environment.

Experiential and involved learning environment

The participants stated that students prefer an environment that allows them to engage in conversations, group activities, role playing and simulations. MacGregor and Semler (2012, p. 242) claim that such an environment provides students with opportunities to develop the critical thinking, analytic skills, judgment, insight, and sensitivity they require to confront the many situations they will face in their future roles. Other participants noted that students also enjoy a classroom set up, but interaction should be facilitated differently from the normal academic set up. In the classroom, students engage in practical exercises, interactive dialogues, presentations and group discussion. One respondent indicated that the classroom environment is most enjoyable for students when it is casual, laid back, and encouraging, with approachable facilitators.

Safe spaces to freely engage and express themselves

The participants also indicated that students prefer a safe space where they can freely express their views. Kisfalvi and Oliver (20I5, p. I2) argue that learning spaces should be challenging and supportive, welcome dissent and difference in a spirit of hospitality and should allow students to enter into safe communication with one another, drawing on their respective life experiences in order to grow. Sinclair (2007:460) states that a safe classroom climate promotes deeper learning.

Off-campus outdoor learning environment

The participants indicated that students display enthusiasm when programmes are presented in an outdoor environment especially in camping facilities off campus. They noted that off-campus programmes attract a large number of participants. Boettcher and Gansemer-Topf (20I5, p. 49) argue that Outdoor Recreation Programmes (ORPs) help students to develop advanced leadership skills and identities which equip them to be more successful citizens and community members. Komives and Wagner (20I7, p. II7) state that powerful, compelling experiences build trust and establish respect among group members. Such experiences include challenge courses, rope courses, outdoor challenge trips, and interesting classroom projects.

Challenges experienced in the delivery of SLDPs

The participants were requested to share the challenges they encounter in delivering SLDPs in their universities. The themes that emerged were: The academic timetable does not allow space for effective delivery of SLDPs; university shutdowns negatively impact delivery of SLDPs; insufficient funding for SLDPs; and lack of buy-in and visible support from senior management.

The academic timetable does not allow space for effective delivery of SLDPs All the participants agreed with this statement. They noted that their universities have removed the lunch hour free period from the timetable. This 
hour used to be used to run most student affairs programmes. As a result, programmes have to be scheduled after hours and over the weekends. However, the university bus schedules, and residence rules have not been adjusted to enable students to attend these programmes. The participants were of the view that those who design the timetable lack appreciation of the contribution made by SLDPs in achieving the institutional objectives which include the development of university graduate attributes and work readiness. This sentiment is echoed by Ching and Agbayani (2019) who argue that although student affairs' positive impact on students' educational success is well-known within student affairs units, this is often not acknowledged in the broader campus community. It is for this reason that Desai (20II) argues that during the timetable generation process, numerous aspects have to be taken into consideration especially the hard constraints and soft constraints. Most of the participants indicated that they are pursuing multiple strategies to navigate these challenges. These include presenting programmes after hours, and during holidays and weekends. On some campuses, transport is provided to commuter students to attend the programmes. Student timetables are analysed to identify free times and programmes are presented during such times. In other universities, Student Affairs units have reduced their contact session hours and posted significant content online for students. Others engage with various academic departments to lobby for a more accommodating timetable.

University shutdowns negatively impact delivery of SLDPs

University shutdown periods in response to student protests also disrupt SLDPs. Furthermore, catch-up plans only consider academic programmes. This makes it difficult for student leadership practitioners to complete their planned activities. Czerniewcz and Trotter (2OI9) observe that student protests and university shutdowns have resulted in some universities using blended and online delivery as a strategy to enable the academic year to be completed.

Insufficient funding for SLDPs

The participants stated that their SLDPs are under-funded. Gansemer and Englin (20I5, p. 73) and Hamrick, and Klein (20I5, p. I6) point to the challenging financial environment in higher education. This has direct implications for student affairs, as it not only reduces resources for its programmes, but results in new waves of student protest. The participants identified their units' different sources of funding, including (I) Compulsory student levies that are solely reserved for on-campus student services; (2) donor funding; (3) third stream income from renting out their facilities and charging fees for their services; (4) fundraising activities, including internal fundraising from sympathetic departments within the university; and (5) grants from the Department of Higher Education and Training. Despite this matrix of funding efforts, they felt that there was still insufficient funding for SLDPs. One of the participants indicated that they receive funding from organisations that fund student scholarships, as the scholarship beneficiaries are offered certain programmes provided by student affairs.

Lack of buy-in and visible support from senior management

All the participants indicated that what is most needed is buy-in and support from senior management. They stated that they seemed to be unable to persuade senior management of the importance of the work that they do. The participants pointed out that while their universities' strategic plans place students at the centre of all their efforts, in practice senior management is distant from the programmes offered by Student Affairs units. They argued that this was clearly reflected in funding decisions, space allocation and decisions on academic timetables. However, the participants in Ching and Agbayani's (20I9) study suggested that student affairs professionals need to engage in self-reflection on whether the lack of support from university management might not be due to their failure to communicate the importance of their role using evidence-based methods. Nevertheless, Pule (20I7, p. 288) suggests on-going communication among different stakeholders, including student leaders and university management, as well as Student Affairs departments and the Department of Higher Education and Training. Davis (20I4, p. IIO) highlights the need to involve senior leaders in leadership initiatives since this is an excellent way to transfer knowledge, values, attitudes, and corporate identity. It also adds gravitas to a programme when busy senior executives are involved as speakers or facilitators. This sends a message to the entire organisation that leadership development is a priority and that it is taken seriously.

\section{Conclusion}

The above findings suggest that the leadership educator may be summarised as a someone who is suitably qualified in Student Affairs with basic skills, competencies and attributes such as (i) sound research acumen, (ii) good writing ability, (iii) presentation and facilitation skills, (iv) ability to conduct a needs analysis, (v) ability to design training programmes, (vi) ability to design learning experiences and materials, (vii) capacity to assess and gauge training, (viii) skills to plan and manage events and projects, (ix) report writing skills and (x) general understanding of student development theories; and someone who is adaptable to change.

The results also showed that most of the student affairs professionals that participated in the study lack knowledge of student affairs theories and models. The participants identified adequate resources, balanced content 
and programmes that address students' needs and aspirations as critical elements for the successful delivery of SLDPs. In terms of essential content of such programmes, they highlighted community service, personal development, communication skills, leadership development and general organisational skills.

The majority of the participants assumed that the programmes they offerd were impactful, yet, they lacked proper instruments and evidence in this regard. Only a few institutions employ systems, tools, and records backed by scientific data and proper tracking to evaluate the impact of their SLDPs. This suggests the need to develop scientific methods to assess the impact of these programmes.

Turning to students' preferred learning environment in relation to SLDPs, the participants stated that students prefer a casual and encouraging environment, with programmes presented in an outdoor environment, especially in off-campus camping facilities. Finally, the challenges confronted by the participants in facilitating SLDPs included timetable congestion, lack of venues dedicated to SLDPs, commuter students being unable to attend sessions after hours and weekends, insufficient funding, the impact of shutdowns and student protests, and a lack of buy-in from management.

\section{Recommendations}

Based on the study's findings, it is recommended that:

- Universities should contribute to the development of an undergraduate qualification in Student Affairs. Furthermore, to ensure that all incumbents are properly equipped a one-year postgraduate diploma should be introduced. Nkonoane (2015, p. I30) proposes that "a four-year foundational study programme could be structured at undergraduate level for the preparation of entry-level Student Affairs practitioners." The senior student affairs officers to whom leadership educators report should also develop educators' capacity in research, writing skills, presentation, and facilitation, needs analysis, programme design, the design of learning experiences and materials, assessment and evaluation, planning and managing events and projects, report writing skills and general understanding of student development theories.

- Student affairs professionals should be made aware of relevant SLDP theories and models. Long (2012, p. 4I) notes that, although this profession is highly practical, the design of educational experiences and programmes should be grounded in theories of student development. Partnerships should be developed between South African universities and those in other countries to facilitate programmes to train staff in South African universities. Local benchmarking exercises should be facilitated in order to enable exchange of information and sharing of resources between universities. This should include staff exchange programmes to facilitate knowledge transfer and transactional learning. Mosier and Schwarzmueller (2002, p. III) explain that "benchmarking is an effective way to improve services and programmes and can assist with uncertainty and rapid change through the discovery of best practices, greater efficiencies, and a clearer understanding of what works most effectively in student affairs."

- An audit should be conducted of all the units responsible for SLDPs to ascertain whether they are adequately resourced with the identified enablers. There should be engagement on these areas to further develop the list. Leadership educators should consider including the following five subject areas as baseline compulsory offerings in the SLDP curriculum: community service, personal development, communication skills, leadership development and general organizational skills.

- Each university should adopt a proper mix of methods to evaluate the impact of their programmes. This should integrate those that are already in use at other universities. Deliberate strategies should be adopted to justify the worth of programmes offered by Student Affairs divisions. This should be led from the top by senior student affairs professionals, flowing down to the most junior member of staff. A practical value proposition for SLDPs needs to be developed by all Student Affairs units, including monitoring of attendance, linking programmes to university strategies, justifying return on investment, documenting positive stories, and tracking former participants.

- Student affairs professionals should design programmes with due consideration for the type of learning environment that will produce the best results for students, taking into account students' preferred learning environments. Leadership educators should be trained to facilitate outdoor and adventure-based programmes.

- Proposals need to be formulated and broader university discussions should be held between Student Affairs, academic faculties, and other operational divisions to address the issue of timetable congestion. There should be a broader university effort to enable maximum participation of commuter students in SLDPs. These efforts should include extending the student bus shuttle timetable and providing other support to commuter students.

\section{Limitations of the study and future research}

The study was based on the experiences of student affairs professionals from six universities in South Africa. As such, the findings cannot be generalised to all universities in the country. 
The study relied on the participants' experiences, raising the possibility of bias. Furthermore, it did not solicit the views of others who might be involved in presenting SLDPs, such as senior students and external facilitators.

In terms of future research, this could include a study on developing a qualification for student affairs professionals. The National Research Foundation (NRF) could be approached to fund a Chair for Student Affairs Professionalisation at one of the universities.

Future research could also focus in more depth on what constitutes a suitable and enabling environment for presenting SLDPs in the South African context, including the use of new technologies and outdoor learning.

Finally, studies should be conducted on the creation of a seamless student affairs environment in South African universities. This would facilitate a more equitable student affairs environment that could form part of the quality assessments performed by the Council for Higher Education. Such research would help to build appropriate systems and structures to enhance the quality of this environment and place the sector in a strategic position to be taken seriously by university management and funders.

\section{References}

Ahlquist, J. (20I5). Developing Digital Student Leaders: A Mixed Methods Study of Student Leadership, Identity, and Decision Making on social media. Thesis, Doctor of Education in Higher Education Leadership. California Lutheran University.

American College Personnel Association and National Association of Student Personnel Administrators. (20I5). ACPA/NASPA professional competency areas for student affairs educators. Washington D.C.

Boettcher, M. L., and Gansemer-Topf, A. M. (20I5). Examining leadership development through student leader outdoor recreation training. Recreational Sports Journal 39(2), 30-49.

Bui, H. M., Ituma, A., and Antonacopoulou, E. (2013). Antecedents and outcomes of personal mastery: Cross-country evidence in higher education. International Journal of Human Resource Management 24(I), I67-I94.

Council for the Advancement of Standards in Higher Education (CAS). (2006). CAS professional standards for higher education. (6th ed.). Washington D.C.

Ching, D., and Agbayani, A. (2019). Student affairs' voice, visibility, and relevance in higher education administration. Journal of College and Character 20(3), I9I-200.

Creswell, J. W. (2009). Research design: Qualitative, quantitative, and mixed methods approaches. (3rd ed.). Thousand Oaks, CA: Sage.

Czerniewicz, L., Trotter, H., and Haupt, G. (20I9). Online teaching in response to student protests and campus shutdowns: academics' perspectives. International Journal of Educational Technology in Higher Education 16(43). I-22.

Davis, P.J. (20I4). Best practice principles in leadership development interventions: An Australian perspective. Journal of Management Policy and Practice 15(5), IO7-II9.

Desai, N.P. (20II). Preferences of teachers and students for auto generation of sensitive timetable: A case study. Indian Journal of Computer Science and Engineering 2(3), Jun-Jul, 46I-465.

Dunn, A.L, Moore, L.L., Odom, S.F., Bailey, K.J., and Briers, G.A. (2019). Leadership education beyond the classroom: Characteristics of student affairs leadership educators. Journal of Leadership Education 18(4), 94-I09. [Online] Available at: https://journalofleadershiped.org/ jole_articles/leadership-education-beyond-the-classroom-characteristics-of-student-affairs-leadership-educators/ [Accessed 2 May 2020].

Gansemer, T. A. M., and Englin, P. D. (20I5). Contemporary challenges in student affairs budgeting and finance. New Directions for Student Services (I5I), 63-78.

Guthrie, K.L., and Jenkins, D.M. (2018). The role of leadership educators in transforming learning. Charlotte, NC: Information Age.

Hamrick, F. A., and Klein, K. (20I5). Trends and milestones affecting student affairs practice. New Directions for Student Services (I5I), I5-25.

Harding, H. E., and Matkin, G. S. (2OI2). Educators experiences teaching leadership. Academic Exchange Quarterly 16(3), I2-I9.

Jenkins, D.M. (2019). Exploring the lived experiences of becoming and being a leadership educator: A phenomenological inquiry. Journal of Leadership Education, 18(3), I4I-I57.

Jenkins, D. M., and Owen, J. E. (20I6). Who teaches leadership? A comparative analysis of faculty and student affairs leadership educators and implications for leadership learning. Journal of Leadership Education 15(2), 98-II3.

Johnson, M. R. (20I9). Advancing a deliberative paradigm to bolster democratic engagement in student affairs. Journal of Student Affairs Research and Practice 56(5), 550-608.

Kisfalvi, V., and Oliver, D. (2015). Creating and maintaining a safe space in experiential learning. Journal of Management Education 39(6), 7I3-740.

Komives, S. R., and Wagner, W. (20I7). Leadership for a better world: Understanding the social change model of leadership development. San Francisco, CA: Jossey-Bass.

Larson, R., and Eccles, J. S. (2005). Organized activities as contexts of development: Extracurricular activities, after school and community programmes. Mahwah, N.J.: Psychology Press.

Lebrón, M. J., Stanley, C.L., Kim, A.J., and Thomas, K.H. (20I7). The 
empowering role of profession-based student organizations in developing student leadership capacity. New Directions for Student Leadership 155, 83-94.

Lin, L., and Shek, D.T.L. (2019). Does service leadership education contribute to student well-being? A quasi-experimental study based on Hong Kong University students. Applied Research Quality Life 14(I), II47-II63. [Online] Available at: https://doi.org/ıo.I007/sir482-or89644-x [Accessed io January 2020].

Long, D. (20I2). Theories and models of student development. In: Hinchliffe, L. J. and Wong, M. A. (eds) Environments for student growth and development: Librarians and student affairs in collaboration, pp. 4I-55. Chicago: Association of College and Research Libraries.

MacGregor, S. P., and Semler, K. (20I2). Towards whole person learning through sustainable executive performance. Journal of Management Development 31, 23I-242.

Major, T.E., and Mangope, B. (20I4). Multicultural competence in student affairs: The case of the University of Botswana. Journal of Student Affairs in Africa 2(I), 23-34.

McMillan, J. H., and Schumacher, S. (2010). Research in education: Evidence-based inquiry. (7th ed.). Boston: Pearson.

Martin, G.L., Smith, M.J., Takewell, W.C., and Miller, A. (2020). Revisiting our contribution: How interactions with student affairs professionals shape cognitive outcomes during college. Journal of Student Affairs Research and Practice 57(2), 148-160.

Morgan, D.L., and Orphan, C.M. (20I6). Student Political Engagement in the Co- Curriculum: Understanding the Role of Senior Student Affairs Officers. Journal of Public Affairs 5(2), 10-39.

Mosier, R. E., and Schwarzmueller, G. J. (2002). Benchmarking in student affairs. New Directions for Higher Education 118(I), I03-II3.

Mouton, J. (200I). How to succeed in your master's and doctoral studies. Pretoria: Van Schaik.

Msila, V. T. (20I5). Ubuntu: Shaping the current workplace with (African) wisdom. Randburg: KR Publishing.

Nkonoane, M.J. (20I5). Capacity building among student affairs practitioners in HEIs in South Africa with regard to student governance. DPhil thesis. Central University of Technology.

Nyumba, T.O., Wilson, K., Derrick, C.J., and Mukherjee, N. (20I7). The use of focus group discussion methodology: Insights from two decades of application in conservation. Methods Ecology and Evaluation 9, 20-32.

Oburn, M. (2005). Building a culture of evidence in student affairs. New Directions for Community Colleges 131, I9-32.

Osmani, M., Weerakkody, V., and Hindi, N. (2OI7). Graduate attributes in higher education: Examining academics' perception in the Middle East. Journal of Education for Business 92(2), 53-68.

Pansiri, B., and Sinkamba, R.P. (20I7). Advocating for standards in student affairs departments in African institutions: University of Botswana experience. Journal of Student Affairs in Africa 5(I), 5I-62.

Pule, N.T. (20I7). The social construction of student leadership in a South African university. DPhil thesis. University of South Africa.

Robinson, J.A., and Glanzer, P.L. (20I6). How students' expectations shape their quest for purpose during college. Journal of Student Affairs Research and Practice 53(I), I-I2.

Rosch, D., Spencer, G. L., and Hoag, B. L. (20I7). A comprehensive multi-level model for campus-based leadership education. Journal of Leadership Education 16(4), I24-I34.

Selznick, B. (20I3). A proposed model for the continued professionalization of student affairs in Africa. Journal of Student Affairs in Africa $\mathrm{I}(\mathrm{I} \& 2)$, II-22.

Seemiller, C. (20I4). The Student Leadership Competencies Guidebook: Designing Intentional Leadership Learning and Development. San Francisco: JosseyBass (The Jossey-Bass Higher and Adult Education Series).

Seemiller, C., and Priest, K. L. (20I7). Leadership educator journeys: Expanding a model of leadership educator professional identity development. Journal of Leadership Education 16(2), I-22. Retrieved from http:// www.journalofleadershiped.org/index.php/issues/20I7-volI6-iss-2/493-leadership-educator-journeys-expanding-a-model-ofleadership-educator-professional-identity-development.

Sinclair, A. (2007). Teaching leadership critically to MBAs: Experiences from heaven and hell. Management Learning (38), 458-472.

Speckman, MT., Mandew, M., and Bawa, A. (2014). Perspectives on student affairs in South Africa. Somerset West: African Minds.

Tesch, R. (1992). Qualitative research: Analysis types and software tools. New York: Falmer.

UNESCO. (2009). Student affairs and services in higher education: Global foundations, issues and best practices. Paris.

Universities South Africa (USAF). (20I8). Membership. [Online] Available at: https://www.usaf.ac.za/membership/. [Accessed 3 May 2020].

Weiss, L. (20I9). The case for soft skills. BizEd 18(I), 40-44.

Wibeck, V., Dahlgre, N. M.A., and Öberg, G. (2007). Learning in focus groups: An analytical dimension for enhancing focus group research. Qualitative Research 7(2), 249-267.

Wilson, A.B. (2013). Exploring the Multicultural Competence of Leadership Educators. Journal of Leadership Education 12(2), Summer, 35-55. 